\title{
The influence of strategy formulation practices on the perceived financial performance of small and medium enterprises: The Zimbabwean experience
}

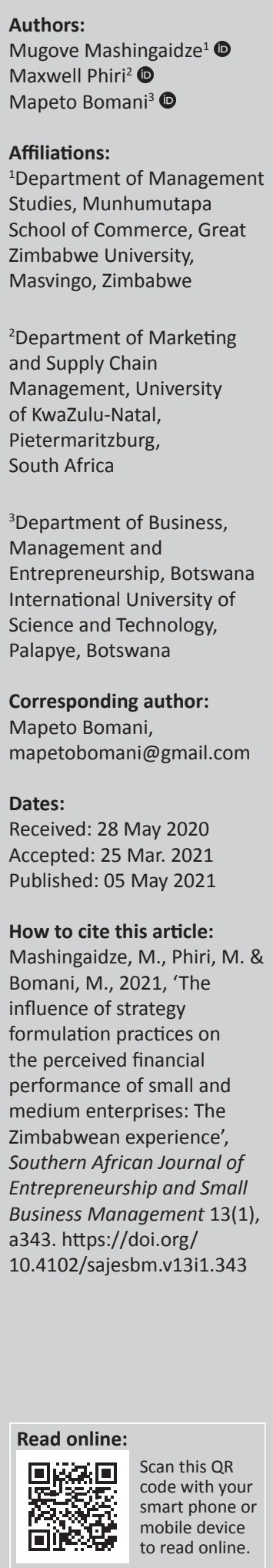

Background: The role of strategy formulation in enhancing the performance of small and medium enterprises (SMEs) has attracted much attention amongst researchers worldwide. However, little research has been conducted on the strategy formulation practices of SMEs and their implications for the perceived financial performance of these firms, especially in the developing world.

Aim: This study was aimed at establishing the impact of strategy formulation on the perceived financial performance of SMEs in Zimbabwe.

Setting: Primary research was conducted in Harare, the capital city of Zimbabwe.

Methods: The study took a case study design in which the researcher collected data from manufacturing SMEs in Harare, Zimbabwe. Stratified random sampling was employed to draw 368 questionnaire respondents from the five manufacturing classes that emerged from the population. Data were analysed using both descriptive and inferential statistics.

Results: The study established that strategy formulation is somewhat prevalent amongst SMEs in Zimbabwe. The five strategy formulation activities as put forward by the theory are found in Zimbabwean SMEs. The results revealed that strategy formulation significantly influences both short-term and long-term perceived financial performance of SMEs in Zimbabwe.

Conclusion: The study has implications at a practical and managerial level. Whilst supporting SMEs is commendable, governments should prioritise the provision of management and entrepreneurial training for SMEs to foster the adoption of strategy formulation. This study suggests that SMEs should make strategy formulation a priority, a key ingredient to the success of their enterprises. It is necessary to inculcate the necessary culture, which supports effective strategy formulation. The study proposes suggestions for future research.

Keywords: strategy formulation; strategy formulation process; financial performance; SMEs; Zimbabwe.

\section{Introduction}

The role of strategy formulation in enhancing the performance of small and medium enterprises (SMEs) has attracted much attention amongst researchers worldwide (Majama \& Magang 2017:75; Monday et al. 2016). The terms 'strategy formulation', 'strategic planning', 'strategy making' and 'strategy development' can be used interchangeably to mean the same thing (Musandiwa 2014:95). According to Sandada (2015:59), there is a 'strong argument from the literature that SMEs need to engage in strategic planning if they are to maintain their position as key economic players'. Strategy formulation is important in strategically positioning firms in changing circumstances (Melo et al. 2018:45). Mattheeusen and Spontak (2018) have further argued that the dynamic nature of the African business environment forces businesses of all sizes to develop and adopt strategic responses to these changes. Strategic formulation is thus an indispensable management tool that cushions SMEs from the volatile operating environment (Ralph et al. 2020). Considering the growing importance of SMEs in Zimbabwe's socio-economic structure, they need to understand the value of strategy formulation in the success of their business (Sandada \& Chikwama 2016).

Although SMEs are responsible for addressing sustainable development in Zimbabwe (Tinarwo 2016:148), these enterprises are faced with many challenges that negatively affect their performance

Copyright: ( 2021. The Authors. Licensee: AOSIS. This work is licensed under the Creative Commons Attribution License. 
and ultimately theirgrowth(Mabenge, Ngorora-Madzimure \& Makanyeza 2020:2). Findings have shown that most SMEs in Zimbabwe close down within the first 5 years of their operation (Sibanda, Hove-Sibanda \& Shava 2018:555) and a smaller percentage face extermination between the 6th and 10th years (Sandada \& Chikwama 2016:95), whilst only 5\% 10\% thrive to maturity (Acquaah \& Agyapong 2015:2; Nyamwanza 2015:125).

Given this background, the need for strategy formulation continues to be on the increase, considering that these small business entities are increasingly threatened by low profit margins and are also plagued with high failure rates (Sandada \& Chikwama 2016:95). Existing findings attribute their high failure rate in Zimbabwe to poor management (Sibanda et al. 2018). Existing literature reveals that lack of strategy formulation amongst SMEs may thwart them from achieving their performance targets and ultimately the potential for survival (Donkor, Donkor \& Kwarteng 2018; Melo et al. 2018:45).

Little research has been conducted on the strategy formulation practices of SMEs and their implications for the perceived financial performance of these firms, especially in the developing world (Majama \& Magang 2017:75). For example, Abosede, Obasan and Alese (2016:331) in Nigeria conducted a literature search to examine the strategic management practices of SMEs and established that academics are yet to agree on the influence of strategic planning on firm performance. In Botswana, Majama and Magang (2017:75) concluded that strategic planning significantly influences firm performance. In Malaysia, Kee-Luen, Hiam-Yong and Seng-Fook (2013:437) observed that manufacturing SMEs who have some form of strategic planning are more likely to perform better in terms of the four perspectives of the balanced scorecard (BSC).

Donkor et al. (2018) explored the influence of strategy formulation on firm performance of SMEs in Ghana and concluded that strategy formulation significantly enhances performance, whilst in Nigeria, Nwachukwu, Chladkova and Fadeyi (2017) established that the strategy formulationperformance relationship is moderated by many environmental factors.

The majority of studies examining strategy formulation-firm performance in Africa have been conducted with samples of firms in Nigeria (Abosede et al. 2016; Nwachukwu et al. 2017), Ghana (Auka \& Langat 2016; Donkor et al. 2018) and South Africa (Dubihlela \& Sandada 2014; Gomera, Chinyamurindi \& Mishi 2018). In Zimbabwe, Nyamwanza (2015) conducted a study to explore the strategy implementation for survival and growth amongst SMEs, whilst Sandada and Chikwama (2016) explored the driving forces for the practice of strategic planning in SMEs in Harare. However, none of these studies dared to investigate the nature of strategy formulation amongst SMEs and the effect thereof on their financial performance in Zimbabwe.
Galbreath et al. (2020) observed that generalising results from other contexts could be misleading because countries have different cultures and idiosyncrasies and firms respond differently to different contexts. In this regard, Shu et al. (2019) called for scholars to research different and new contexts. The article thus takes a Zimbabwean perspective. Zimbabwe is a sub-Saharan African country that has experienced political and economic instability since 2000 . The economic turbulence, partly blamed on the land reforms, poor political relations with the West, policy inconsistency and corruption has led some large corporates to either downsize or relocate their facilities (Chinakidzwa \& Phiri 2020; Mugozhi \& Hlabiso 2017). This departure of large corporates has created huge opportunities for SMEs in the manufacturing sector (Chinakidzwa \& Phiri 2020). In order to enhance their performance, strategy formulation could play an important role. This, therefore, calls for the need to explore the relationship between strategy formulation and financial performance in a turbulent environment. This article provides empirical evidence from a Zimbabwean context. Moreover, within the Zimbabwean SME context, the article extends previous research on strategy formulation practices. We believe our study to be the first to explore the strategy-making process of SMEs in Zimbabwe and its influence on their financial performance. Hence, this article is a distinctive contribution to the body of knowledge.

This study's aim was to examine the impact of strategy formulation on SME financial performance in Harare, Zimbabwe, with the specific objectives of examining the practice of strategy formulation in Zimbabwean manufacturing SMEs and the establishment of the relationship between strategy formulation and the perceived financial performance of SMEs in this context. The remainder of the article is structured as follows: The next section presents the review of literature, followed by the research methodology, findings of the study and conclusion. Finally, the article presents the study's limitations and directions for future research in the last section.

\section{Literature review Strategy formulation}

Strategy consists of the combination of competitive moves and business approaches that managers employ to please customers, compete successfully, conduct operations and achieve organisational objectives (David \& David 2016). Monday et al. (2016:138) viewed strategy development as managers' response to the opportunities and constraints presented by their marketing environment. Lynch (2015:20) defined strategy formulation as 'a process of finding a match between organisational capabilities and opportunities that are present within the competitive environment', whilst Auka and Langat (2016:2) defined it as 'the process of selecting the most appropriate course of action for the attainment of organisational goals and objectives and, thus, facilitating the realisation of both long-term and short-term objectives'. The given definitions emphasise that strategy formulation accords with the organisation's environment, resources and strategic 
objectives. Musandiwa (2014:112) stressed the need for SME owner-managers to determine how the whole process of strategy formulation should be conducted to ensure that they develop sound and credible strategies.

The literature on strategic management has a range of strategy formulation models (Musandiwa 2014:115). In his early work, Mintzberg (1994) identified three main ways in which strategies are developed: the planning model, the entrepreneurial model and the learning by experience model. He describes the planning model as a fully controlled thought out process for strategy making. Mintzberg's view is shared by many leading scholars such as Wheelen et al. (2014), Thompson et al. (2016), David and David (2016) and Hill and Jones (2013). These scholars agree that strategy making is a linear process through many steps (Pitt \& Koufopoulos 2012:15); hence, the first distinguishing factor in the strategymaking process is formalisation (Musandiwa 2014). The second strategy-making model is the entrepreneurial model.

According to Feurer and Chaharbaghi (1997:13), this model yields both personal and informal plans.

Musandiwa (2014:96) claimed that the entrepreneurial model is mostly found in organisations where an owner or entrepreneur owns and controls the business. Thus, it is found in entrepreneurial businesses (Mintzberg, Ahlstrand \& Lampel 2009:146). The outcome of this model is entrepreneurial strategies that are imposed through the owner-managers' personal control. The third model is the learning by experience model, in which, according to Mintzberg et al. (2009:147), strategies develop from adjustments and dynamics within the business environment. With the learning by experience model, strategy formulation and implementation take place at the same time (David 2015). This is in contrast to the planning model, where a strategy is formulated and the execution takes place at a later stage.

Musandiwa (2014:115) posited that no one strategy formulation model is superior to any others. Cokins (2017) emphasised that what is important is that strategy development must be grounded on thorough situational analysis. Mindful of these planning models, Papulova and Papula (2014:114) claimed that strategy formulation can either be deliberate or emergent. Researchers who advocate for the planning process argued that strategy formulation must be seen as an analytical and systematic process (David 2015:45). Systematic strategy formulation makes it more likely that breakthrough business strategies are developed. Similarly, De Wit and Meyer (2014:121) believed that strategy development should be a conscious step-by-step process. The following section examines the strategy formulation process in detail.

\section{Strategy formulation process}

Musandiwa (2014:100) claimed that strategies are intentionally created in the same way as a bridge is designed by a team of engineers. In the same spirit, Burugo and Owour
(2017:925) viewed strategy development as 'a rational, analytical and deliberate process in which goals are stated; in-depth analysis is conducted; the planner, analyst and executives develop a formal and comprehensive strategy'. Hence, this is a process that, when executed effectively, produces a breakthrough strategy enabling SMEs to fulfill their objectives (David 2015:74). The following section examines the steps followed in the formulation of business strategies in greater detail.

\section{Development of the strategy purpose}

The first step in strategy formulation is to develop the strategic purpose that is the mission and vision of the organisation (Verreynne, Meyer \& Liesch 2014:6). The mission statement provides the background onto which the strategy is crafted (David \& David 2016:344); it gives the unique purpose of an organisation, that is, its business (David 2015:40) and distinguishes one business organisation from another (Adeyemi, Isaac \& Olufemi 2017:114). The vision statement establishes what the organisation wants to become in the future (David 2015:75). Thus, the two can be combined to produce a strategic mission statement (Gates 2013).

\section{Establishing strategic objectives}

Auka and Langat (2016) observed that setting objectives is a key component in the strategy formulation process. Adeyemi et al. (2017:110) defined strategic objectives as the performance targets needed to accomplish the organisation's key purpose. Strategic objectives are needed to assess the success of organisations (Jones \& Hill 2010:16). Thus, they provide direction on how the organisation fulfills its strategic purpose as specified in the mission statement (Dess, Lumpkin \& Eisner 2010:29). However, Verreynne et al. (2014:6) emphasised that the strategic objectives need to be consistent with the mission statement.

\section{Environmental scanning}

The survival of an organisation is conditioned by its environment (Aldehayyat 2015:469). Thus, organisations, both small and large, need to monitor their environment to adapt and respond (David 2013:40).

Successful alignment of marketing strategies with environmental conditions is dependent on effective environmental scanning. According to David (2015:72), a firm's environment consists of three facets: the internal environment, the industry environment and the macro (mega) environment. Changes in each facet present a challenge to organisations to remain relevant (Wheelan \& Hunger 2014:37). Ultimately, environmental scanning becomes a necessity for effective strategy formulation (Aldehayyat 2015:469).

\section{Integration of environmental data}

The analysis of the business environment helps to identify its internal strengths and weaknesses and its external threats and opportunities (Melo et al. 2018:45). According to Du Toit (2016:18), a successful strategy formulation requires firms to 
integrate both internal and external data from their environment. Thus, one strategic tool that can be used by managers to assist in generating practical and reliable strategies is the strengths, weaknesses, opportunities and threats (SWOT) framework (Analoui \& Karami 2013:129; David \& David 2016). The acronym SWOT stands for strengths, weaknesses, opportunities and threats (Thompson et al. 2016). The framework is based on the recognition that effective strategies enable firms to mitigate the adverse impacts of threats and weaknesses (Hadighi et al. 2013:38) and also to capitalise on their opportunities and strengths (Carlsern \& Andersson 2011:86). Hay and Castilla (2006:2) cited in Musandiwa (2014:123) posed the following questions that managers should answer in strategy formulation: how can businesses use the strengths they have? How can businesses stop their weaknesses? How can businesses exploit each of their opportunities? How can businesses defend themselves against threats? Thus, Helms et al. (2011) claimed that the ability of firms to develop SWOT analysis will allow them to develop well-informed business strategies.

\section{Strategy analysis and choice}

Singh (2009:265) observed that the 'analysis and choice stage of the strategy formulation process involves the development of various strategies leading to the selection of the best strategy to pursue'. This stage is essentially a decision-making process involving three main steps: firstly, identifying alternative strategies; secondly, evaluating the alternatives; and, thirdly, selecting the most appropriate strategic option. Thus, during this last stage firms ought to examine their own internal or corporate characteristics and capabilities and identify the most important features of the external environment within which they must operate (Sami 2016:53). Similarly, David (2015:231) asserted that the selection of the ultimate strategy is a negotiated outcome between the organisation's resources, competencies and the opportunities from the external environment.

This section has provided the strategy formulation process informed by strategic management theory (Carlsern \& Andersson 2011; David 2013; David 2015; Hill \& Jones 2013; Lynch 2015; Mintzberg et al. 2009). The strategy formulation steps, as identified in the literature, are not isolated but are interdependent (Mintzberg et al. 2009). Researchers are yet to agree on the strategy formulation processes of SMEs (Musandiwa 2014; Nwachukwu et al. 2017). Some argue that the process does not reveal exhaustive strategic analysis (Nyamwanza 2015; Sami 2016). This is subject to research in this study.

\section{Financial performance}

According to Pucci, Nosi and Zanni(2017:12), the measurement of SME's financial performance is, unquestionably, one of the critical aspects of management and entrepreneurship research. Ordinarily, SMEs prefer financial indicators in assessing their performance (Ahmad 2014; Pucci et al. 2017). Pucci et al. (2017:13) posited that finance is the corporate heart of any business. This means that decisions should be made according to their financial return. Furthermore, users of financial indicators argue that organisational finances are a valuable pool of resources for future growth that assist firms to pursue their growth strategy (Salloum et al. 2016:24). According to Chong (2008:7), cash generation and profitability are significant aspects in SMEs' capacity to attain their long-term non-financial goals such as innovativeness, reputation and quality, and hence the use of financial measures in this study. Furthermore, financial performance indicators are regarded as objective and easily interpretable for comparative analysis (Raymond et al. 2013:470).

This study used the financial performance indicators of sales revenue, profit, cash flows, earnings before interest and tax, return on capital employed and return on total assets. Despite their continued use in strategic management research, Raymond et al. (2013) posited that they are not readily available in the public domain and most SMEs do not have the data (Salloum et al. 2016:25). However, in this study, the researchers adopted a subjective approach in assessing firm financial performance following the recommendations of Harif, Hoe and Ahmad (2013) and Mageto, Prinsloo and Luke (2018), that in the absence of objective financial data, researchers may use relative and perceived measures of financial performance. Thus, in this study, the participants were asked to indicate their financial performance trend for the past 3 years on the seven-point Lickert scale.

\section{Review of empirical studies}

Melo et al. (2018) recommended that businesses of all sizes engage in strategic planning practices in order to survive volatile environments. The empirical evidence on the practice of strategy formulation, as well as its impact on performance in SMEs, is inconclusive. This section offers a discussion of the findings from previous studies on strategy formulation amongst SMEs. The finding of Abosede et al. (2016) is that not all SMEs formally plan, but of those that plan formally, the majority tend to do so inconsistently and infrequently.

Pratiwi et al. (2017:8650) investigated the strategic planning of SMEs in Malaysia and concluded that in instances where strategic planning is adopted, it is often unstructured and irrational. Omsa, Ridwan and Jayadi (2017:77) observed that often the strategy process is based on unreliable and insufficient information, usually gathered through informal means. David and David (2016) concurred and add that when entrepreneurs employ strategic thinking, these activities are rarely rational and logical because of insufficient resources and lack of expertise.

However, Cheng, Kadir and Bohari (2014) found conflicting results. They examined the relevance of the deliberate strategic planning to SMEs and whether the Wheelen and Hunger (2014) strategic planning model for SMEs could be applied in the Asian context. The results of the study revealed that the majority of SMEs in Asia have strategic planning processes that resemble the Wheelen and Hunger (2014) 
model. Thus, they concluded that Asian SMEs prefer developing rational strategy formulation. In another study in the United States of America, Wang et al. (2015) conducted a quantitative study to interrogate the barriers to planning in SMEs and observed that ownership motivations are key to understanding strategic planning practices of SMEs.

The study revealed that higher levels of strategic planning are found in SMEs with owner-managers who are growth orientated and lower levels existed in those SMEs with owner-managers who pursue personal agendas.

In Sweden, Tell (2010) conducted a study aimed at generating a better understanding of the strategic planning behaviour of top managers in small, fast-growing manufacturing firms. Empirical data were collected by both the survey approach and structured observations. The findings indicated that SME managers in fast-growing firms are engaged in many different activities, ranging from operational (production, marketing and sales) to administrative (firm personnel and financial issues). Thus, these managers spend very little time on strategic planning. Tell (2010) claimed that this could explain why growth in some firms may decline or cease.

Strategy formulation is considered a fundamental strategic management aspect that enhances firm performance, especially in the unstable and dynamic business world (Auka \& Langat 2016; Melo et al. 2018).

Earlier research work (Abosede et al. 2016; Burugo \& Owour 2017; Donkor et al. 2018; Pucci et al. 2017; Sandada \& Chikwama 2016) showed that successful SMEs appreciate the role of strategy formulation and make greater use of the strategy formulation tools such as SWOT analysis. Mattheeusen and Spontak (2018) investigated the effect of strategy formulation on SMEs' financial performance, establishing that it had a significantly positive influence on firm performance.

In the emerging economies, Kee-Luen et al. (2013) concluded that SMEs practising strategic planning are more likely to perform better on the four perspectives of the BSC, namely, learning and innovation, financial, customer and internal business process perspectives. Similarly, Pashaa and Poisterb (2017) confirmed the overall positive effect of strategy formulation on SMEs' long-term and short-term financial performance. In another study, Siddique (2015:22) concluded that strategy formulation significantly impacts overall SME performance.

In Africa, Nigeria in particular, Nwachukwu et al. (2017) confirmed that strategy formulation significantly increased SME competitiveness and performance. In South Africa, Gomera et al. (2018:45) investigated the relationship between strategy formulation and financial performance of South African SMEs in the Buffalo City Metropolitan and found out that strategy formulation and financial performance were positively and strongly related. Donkor et al. (2018) explored the influence of strategy formulation on firm performance of SMEs in Ghana and concluded that strategy formulation significantly enhances SME performance. In Nigeria, Nwachukwu et al. (2017) established that the strategy formulation-performance relationship is moderated by many environmental factors. The review of literature by Dauda, Akingbade and Akinlabi (2010) established that some studies reported a positive relationship whilst others showed non-existence of a relationship. Studies conducted by Shrader, Mulford and Blackburn (1989), Birley and Westhead (1990) and Covin (1991) found insignificant relationship between strategy formulation and firm performance. Fulmer and Rue cited in Musandiwa (2014) conducted a quantitative study in the United States of America to establish the influence of strategy formulation on the performance of SMEs, but their findings failed to establish any valid relationship between rational long-term planning and financial performance. The study found no differences in sales growth, return on sales and earnings growth between those groups who had formal planning and those who did not plan. In the United Kingdom, Falshaw, Glaister and Tatoglu (2006) conducted a survey to investigate the impact of strategy formulation on firm performance. The findings of the study indicated an absence of a relationship between formal strategic planning and firm performance. In the same vein, Sarason and Tegarden (2003) cited in Germanos (2012) also investigated the influence of strategy formulation on the performance. The study was descriptive and found weak support for the relationship.

The review of literature is testimony that the majority of researchers have accepted that strategy formulation enhances firm performance, whilst a few still reject the direct and positive relationship. The review found no document on the strategy formulation practices of SMEs and the relationship between strategy formulation and financial performance in Zimbabwe. Hence, this study sought to explore the strategy formulation practices of SMEs in Zimbabwe and their impact on financial performance. The study hypothesises that strategy formulation is significantly and positively associated with SME perceived financial performance.

\section{Research methodology Study design}

A case study design was used in this research. Data collection was conducted in Harare, the commercial nerve centre of Zimbabwe. The researcher adopted the case study strategy by focusing only on manufacturing SMEs in Harare. The overall aim of adopting a case study strategy was to obtain an in-depth understanding of strategy formulation in SMEs and its influence on their perceived financial performance in Zimbabwe whilst focusing only on a single case of study (the manufacturing SMEs). The selection of this case study was not based on a random choice, but rather a considered decision based on its role in the country's economy.

\section{Study population}

Sekaran and Bougie (2016) stated that the relevant population may be apparent from the main research question. 
TABLE 1: Sample size per strata.

\begin{tabular}{lccc}
\hline Sector & $\begin{array}{c}\text { Proportion of total } \\
\text { respondents (\%) }\end{array}$ & $\begin{array}{c}\text { Population in } \\
\text { sector }\end{array}$ & Sample size \\
\hline Food products & 22 & 2033 & 81 \\
Clothing \& footwear & 15 & 1386 & 55 \\
Wood \& furniture & 30 & 2773 & 110 \\
Chemical \& petroleum & 10 & 924 & 37 \\
Metals & 23 & 2125 & 85 \\
\hline Totals & $\mathbf{1 0 0}$ & $\mathbf{9 2 4 2}$ & $\mathbf{3 6 8}$ \\
\hline
\end{tabular}

Hence, the main research question guided the researcher to the study's population. All registered manufacturing SMEs in Harare were targeted. According to the 2012 FinScope Survey, Zimbabwe has 3.4 million SMEs (Bomani 2017). Of these, $13 \%$ are in Harare, and 9242 (2.1\%) are found in the manufacturing sector, the target population. The study targeted all manufacturing SMEs located in both the residential areas and the light industrial areas of Harare.

\section{Sampling and sample size}

The target population was divided into five manufacturing classes, five mutually exclusive groups emerging from the population: food products, clothing and footwear, wood and furniture, metals and chemicals.

Yamane's 1967 formula was used to determine the study's sample size of 368 from a population of 9242 .

The formula is most appropriate with stratified sampling (Anyanga \& Nyamita 2016; Kowo, Sabitu \& Adegbite 2018). According to Yamane, the formula for calculating a sample size is:

$$
\frac{N}{\left(1+N(e)^{2}\right)}
$$

Given the 9242 manufacturing SMEs in Harare, the required sample size was 368 , calculated as illustrated here, where:

$N=$ Population size $(9242)$

$e=$ Degree of accuracy (5\%), expressed as a proportion (0.05), is the margin of error.

$\mathrm{n}_{\mathrm{o}}=\frac{N}{1+N(e)^{2}}$

$$
\begin{aligned}
& \mathrm{n}_{\mathrm{o}}=\frac{N}{1+\frac{N^{2}-1}{N}} \\
& \mathrm{n}_{\mathrm{o}}=\frac{9242}{1+9242\left(0.05^{2}\right)}
\end{aligned}
$$

Therefore, $\mathrm{n}=\frac{383.405}{1+\left(\frac{383.405}{9242}\right)}$

$=\frac{383.405}{1.041}$

$=368$

[Eqn 2]
The final study participants were proportionally selected from the different sectors using simple random sampling. Table 1 shows the sample size from each stratum.

The sample size in this study is 368 - more than 30 but less than 500. Thus, the sample size fits Roscoe's (1975) rule of thumb, which says that where the sample can be classified into subgroups the sample size should be at least 30 for each category (Sekaran \& Bougie 2016:269).

\section{Data collection and instrumentation}

Data were collected through a self-administered structured questionnaire, distributed to SMEs for a period of 3 months between February and May 2019. The questionnaire consisted of three sections. Section A aimed at soliciting demographic characteristics of both the study participants and the participating firms. Section B solicited for strategy formulation activities. Section C covered the short-term financial performance. Section D covered the long-term financial performance. The items used to measure the constructs were adapted from the literature, that is, items for strategy formulation were borrowed from David and David (2016), Lynch (2015), Singh (2009), Sandada (2015), Sandada and Chikwama (2016), and Wheelen and Hunger (2014) cited in Nwachukwu et al. (2017). Items for financial performance were borrowed from Mageto et al. (2018), Germanos (2012), Wang et al. (2015) and Makanyeza and Dzvuke (2015). However, the items were modified to suit the present study. Based on a five-point Likert scale, the respondents were requested to indicate their level of agreement with statements regarding strategy formulation and perceived financial performance. The response points were as follows: 1 , strongly disagree; 2, disagree; 3 , neither agree nor disagree; 4, agree; and 5, strongly agree. The Likert scale made it easier for the researcher to code and analyse data from the questionnaires.

\section{Data analysis}

Data gathered were cleaned and coded with the help of the Statistical Package for the Social Sciences (SPSS) Version 23. Data were presented in the form of easy-to-interpret tables. Descriptive statistics such as mean and standard deviation were used to summarise the data, whilst inferential statistics allowed the researcher to examine the relationship between study variables. Pearson's product-moment correlation coefficient was computed to determine the strength of the relationship between strategy formulation and perceived financial performance.

\section{Validity and reliability}

The researchers ensured validity by asking questions that were in line with the research objectives and backed by theoretical and empirical literature. Besides this, some questions used were adapted from questionnaires from previous studies (see the section 'Data collection and instrumentation'). The principal researcher sought expert evaluation from the supervisor during the development of the questionnaire. In order to ensure that 
TABLE 2: Cronbach's alpha for the strategy formulation and perceived financial performance scale.

\begin{tabular}{lcccl}
\hline Section & $\begin{array}{c}\text { Valid cases } \\
(N)\end{array}$ & $\begin{array}{c}\text { Number } \\
\text { of items }\end{array}$ & $\begin{array}{c}\text { Cronbach's alpha } \\
\text { coefficient }\end{array}$ & Comment \\
\hline Strategy formulation & 289 & 25 & 0.885 & $\begin{array}{l}\text { Internally } \\
\text { reliable }\end{array}$ \\
$\begin{array}{l}\text { Short-term financial } \\
\text { performance }\end{array}$ & 289 & 3 & 0.827 & $\begin{array}{l}\text { Internally } \\
\text { reliable }\end{array}$ \\
$\begin{array}{l}\text { Long-term financial } \\
\text { performance }\end{array}$ & 289 & 3 & 0.817 & $\begin{array}{l}\text { Internally } \\
\text { reliable }\end{array}$ \\
\hline
\end{tabular}

the questionnaire measured the impact of strategy formulation on perceived financial performance in SMEs, the researcher carefully planned the research methodology that consisted of sampling, appropriate instrumentation and appropriate statistical treatment of the data (Sekeran \& Bougie 2016). In order to ensure reliability, the questionnaire was pilot tested in Chegutu town, located south-west of Harare. The internal consistency of the questionnaire was then determined via Cronbach's coefficient alpha. Cronbach's alphas for the measuring instruments are shown in Table 2.

In this study, Cronbach's alpha for each of the scales of the variables was tested and found to range from 0.817 to 0.885 , implying that the instrument was highly reliable (Saunders, Lewis \& Thornhill 2016:480).

\section{Ethical considerations}

The principal researcher applied for an ethical clearance and it was obtained from the University of KwaZulu-Natal's research committee (HSS/0507/018D) and a letter of permission was also obtained from the Ministry of Industry, Commerce and Enterprise Development (reference number $\mathrm{NP} / 33 / 448$ ). Thus, the researchers proceeded to data collection knowing very well that the respective authorities had consented to the study.

Throughout the research process, the researchers ensured transparency, honesty, faithfulness and trustworthiness. As such, the study participants were eager to participate and ultimately return the completed questionnaires.

\section{Presentation and discussion of findings \\ Sample composition}

A total of 368 questionnaires were distributed to respondents, of which 304 were returned and 15 were discarded owing to incomplete responses on different parts of the questionnaire. A total of 289 questionnaires were finally used in the study. Therefore, the response rate was approximately $83 \%$. The study results indicate that men (55\%) participated more than women (45\%). Regarding age distribution, the results revealed that the majority $(58.8 \%)$ of the respondents were aged between 32 and 53 years. Mutengezenwa (2018) explained that these economically active people would want to raise their standard of living through operating small businesses, as formal employment opportunities in Zimbabwe have shrunk. The results of the study also showed that $65.0 \%$ of the respondents had at least a diploma, evidence of a high degree of literacy. Thus, the results indicated that most of the entrepreneurs in Harare have formal tertiary education, which assists them in managing their ventures (Tinarwo 2016:149). These findings complement the general literacy rate of Zimbabwe, currently pegged at 92\% (Mbengo 2016:212).

In this study, the majority $(88.2 \%)$ of the sampled enterprises had been in existence for fewer than 10 years. These results validate Bomani's (2017:273) study of SMEs in Harare, which found that $90 \%$ of SMEs had fewer than 10 years experience in business. This is an indication that SMEs in Zimbabwe are still in their infancy (Bomani 2017:273). The results of the study showed that $97.6 \%$ of the surveyed enterprises employ between 5 and 20 employees, whilst none employed between 41 and 75 employees. It was also revealed that the majority of the participating firms (68.5\%) had an annual turnover of less than $\$ 2000000$. These findings are evidence that most manufacturing enterprises are small and reflect that, generally, SMEs cannot employ a large number of permanent employees (Nyamwanza 2015:08).

\section{Strategy formulation amongst SMEs}

The results from the five aspects of strategy formulation are shown in Figure 1.

Figure 1 shows that the majority of respondents (66.0\%) indicated that they are involved in setting the strategic purpose and $64.0 \%$ have strategic objectives. Most of the respondents $(66.0 \%)$ indicated that they are involved in environmental scanning, whilst $64.0 \%$ indicated that they integrate data from all sources to formulate their strategies. An equal number $(60.0 \%)$ of the respondents held the opinion that they have a systematic method of selecting their best strategy. Thus, to a certain extent, SMEs in Zimbabwe practise strategy formulation in their business.

The findings of this study resonate well with other studies in the developed world. In their study of strategic process approaches of SMEs in Australia, Wiesner and Millett (2012) found out that $66.7 \%$ of SMEs are involved in strategy formulation. Chen and Liu's (2012) study concluded that $73.0 \%$ of SMEs have well-established business planning systems. However, these results dismiss the allegation that some SMEs do not engage themselves in strategy formulation (Abosede et al. 2016 in Nigeria and Pratiwi et al. 2017 in Malaysia). These findings support the claim by Mattheeusen and Spontak (2018) that given the volatile nature of the business environment in Africa, SMEs should develop strategic responses to cushion themselves from the changing circumstances. As such, environmental dynamism drives SMEs to strategy formulation (Sandada \& Chikwama 2016:96).

Of interest is that the findings do not support the claim by Omsa et al. (2017) that SME strategy process is based on unreliable information gathered through informal means. 


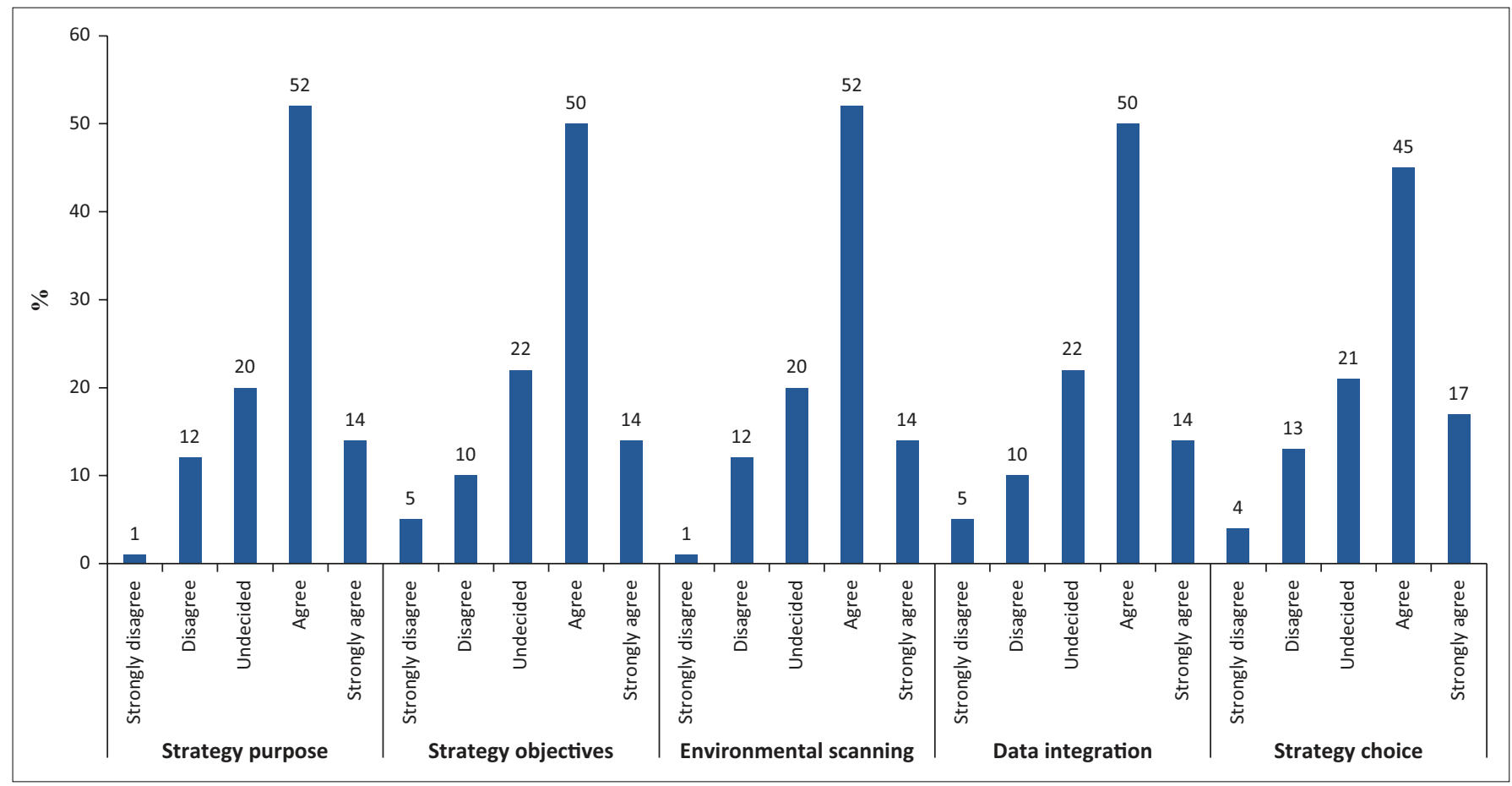

FIGURE 1: Summary of strategy formulation amongst small and medium enterprises.

TABLE 3: Overall means of five activities.

\begin{tabular}{lccc}
\hline Description & $\boldsymbol{N}$ & Mean & Standard deviation \\
\hline Setting strategic purpose & 289 & 3.674 & 0.895 \\
Strategic objectives & 289 & 3.583 & 0.923 \\
Environmental scanning & 289 & 3.656 & 0.896 \\
Data integration & 289 & 3.684 & 0.888 \\
Making choices & 289 & 3.601 & 0.960 \\
\hline
\end{tabular}

TABLE 4: Strategy formulation and short-term financial performance model summary.

\begin{tabular}{lcccc}
\hline $\boldsymbol{R}$ & $\boldsymbol{R}$-square & Adjusted $\boldsymbol{R}$ square & Standard error & Observations \\
\hline 0.783 & 0.613 & 0.652 & 3.865 & 289 \\
\hline
\end{tabular}

The findings illustrate that the limited resources and expertise on the part of the entrepreneur does not affect the undertaking of important strategic management activities such as strategy formulation. The five activities were analysed for their overall means, as depicted in Table 3.

Table 3 shows that all the means were above the third score of the Likert scale, providing further evidence that the SME owner-managers either moderately or strongly agreed that these activities are important in strategy formulation. The dimension of data integration was highly ranked with a mean value of 3.684 , followed by setting strategic purpose $($ mean $=3.674)$ and environmental scanning $($ mean $=3.656)$. The least ranked factors were making strategic choices (mean $=3.601$ ) and strategic objectives (mean = 3.583). This indicates that the SME owner-managers perceived data integration as the most important dimension of strategy formulation. The high mean values of strategic purpose, environmental scanning, making strategic choices and strategic objectives also imply that they had similar views that these activities are also key elements in formulating their business strategies. Previous studies have confirmed the importance of integrating both external and internal data in successful strategy making (Musandiwa 2014). David and David (2016) claimed that the ability of firms to synchronise internal and external data enables them to develop appropriate breakthrough strategies. Research also acknowledges that during environmental scanning, SMEs discover opportunities and threats that shape their future performance (Ralph et al. 2020) and drive their organisation in new directions (David 2015). Overall, the results of the study reveal that the strategic planning processes of most SMEs resemble the Wheelen and Hunger (2014) strategic planning model.

\section{Strategy formulation and financial performance}

Tables 4 and 5 show the results of the statistical analysis to determine the relationship between strategy formulation and financial performance.

The findings of the study revealed that strategy formulation is positively and strongly connected to both short-term and long-term financial performance in manufacturing SMEs $(r=$ $0.783, r=0.817$, respectively). Moreover, the study's findings illustrate that strategy formulation enhances long-term financial performance much more than short-term financial performance. The findings are consistent with some previous investigations available in the literature (e.g. Nwachukwu et al. 2017 in Nigeria; Gomera et al. 2018 in South Africa; Donkor et al. 2018 in Ghana). The findings also validate the claim by Thompson et al. (2016) that:

[T] he essence of good strategy making is to build a market position strong enough and an organisation capable enough to produce successful performance despite unforeseeable events, potent competition and internal difficulties. (p. 17) 
TABLE 5: Strategy formulation and long-term financial performance model summary.

\begin{tabular}{lcccc}
\hline $\boldsymbol{R}$ & $\boldsymbol{R}$-square & Adjusted $\boldsymbol{R}$-square & Standard error & Observations \\
\hline 0.817 & 0.667 & 0.649 & 3.804 & 289 \\
\hline
\end{tabular}

TABLE 6: Strategy formulation and financial performance regression weights model.

\begin{tabular}{|c|c|c|c|c|c|c|c|}
\hline \multirow[t]{2}{*}{ Model } & \multicolumn{2}{|c|}{$\begin{array}{l}\text { Unstandardised } \\
\text { coefficients }\end{array}$} & \multirow[t]{2}{*}{$\begin{array}{l}\text { Standardised } \\
\text { coefficient: } B\end{array}$} & \multirow[t]{2}{*}{$T$} & \multirow[t]{2}{*}{ Sig. } & \multicolumn{2}{|c|}{$\begin{array}{l}\text { Collinearity } \\
\text { statistics }\end{array}$} \\
\hline & $B$ & Std. error & & & & Tolerance & VIF \\
\hline Constant & 5.96 & 0.945 & - & 5.518 & 0.000 & 1.000 & 1.000 \\
\hline $\begin{array}{l}\text { Strategy } \\
\text { formulation }\end{array}$ & 0.658 & 0.004 & 0.135 & 3.923 & 0.002 & 0.861 & 1.403 \\
\hline
\end{tabular}

VIF, Variance Inflation Factor; Std. error, standard error; Sig., significance

This claim implies that organisations that engage in strategy formulation can enhance their competitiveness and consequently improve their financial performance significantly. The findings do not support earlier findings by Falshaw et al. (2006) in the United Kingdom, whose study's findings indicated the absence of a relationship between strategic planning and firm performance.

Table 6 shows the multiple regression analysis (MRA) of the data. The results of the MRA show that there is a statistically significant and positive relationship between strategy formulation and perceived financial performance of manufacturing in Harare $(\beta=0.658, t=3.923, p<0.05)$ :

- Predictors: (Constant), strategy formulation

- Dependent variable: Perceived financial performance

These results imply that a unit increase in strategy formulation index leads to a 0.658 increase in combined SME perceived financial performance. Thus, the hypothesis was accepted. However, as the variables under investigation are only two, the tolerance and VIF are normally one (Hair et al. 2019).

The study's results are in line with previous findings in both developed and emerging economies (Burugo \& Owour 2017; Pashaa \& Poisterb 2017; Pucci et al. 2017; Siddique 2015). These studies concluded that successful SMEs appreciate the role of strategy formulation and make greater use of tools such as SWOT analysis to enhance their performance. Thus, these results entail that strategic planning is a veritable vehicle for improving SME financial performance. These results donate support to the claim that the lack of strategy formulation amongst SMEs may thwart these enterprises from achieving their performance targets and ultimately their potential for survival (Donkor et al. 2018).

\section{Conclusion and managerial implications}

The present study sought to enhance an understanding of strategy formulation practices of SMEs and the influence thereof on their perceived financial performance. It specifically sought to determine the extent of strategy formulation prevalent in SMEs in Zimbabwe, to determine the financial performance implications on these firms.
The study concludes that all the SME categories in Zimbabwe are somewhat involved in strategy formulation. The five strategy formulation activities, as stipulated by De Wit and Meyer (2014), Musandiwa (2014:100), Burugo and Owour (2017:925) and David (2015:74) - namely, development of the strategy purpose, establishing strategic objectives, environmental scanning, integration of environmental data and strategy analysis and choice - are somewhat prevalent amongst SMEs in Zimbabwe. The perceived financial performance of SMEs has increased for the period over which they were formulating strategies. The study also concludes that, overall, strategy formulation positively predicts their financial performance.

These results imply that the influence of strategy formulation on a firm's financial performance differs and is relatively greater in the long term than in the short term. As there has not been any research on the influence of strategy formulation on financial performance in Zimbabwe, the present study provides groundbreaking evidence. As such, the empirical findings have important academic and managerial implications. It is generally agreed in the literature that strategy formulation drives the performance of enterprises (David \& David 2016; Lynch 2015; Mattheeusen \& Spontak 2018; Ralph et al. 2020). Based on the empirical findings of the present study, SMEs should make strategy formulation a priority, as a key ingredient to the success of their enterprises. Along with this, it is necessary to determine the required culture with which to support effective strategy formulation for enhanced financial performance.

According to Donkor et al. (2018:63), most governments in developing countries have come up with programmes that support SME training in enterprise management and administration. Especially in developing countries such as Zimbabwe, SMEs should take advantage of the efforts of their governments and embrace strategic management principles in their day-to-day activities. Governments are encouraged to continue with these policies targeted at providing training and workshops on enterprise management for SMEs to adopt strategic management fundamentals such as strategy formulation to enhance their performance. Moreover, SMEs in Zimbabwe should not wait for government support to augment their performance and growth; instead, they should engage in strategy formulation to establish breakthrough strategies that enhance their performance.

This requires a willingness by SME owner-managers to develop a more futuristic and strategic approach.

However, particular attention should be given to long-term financial performance, which was found to significantly improve because of strategy formulation.

\section{Limitations and future research}

Despite the insights gained from this study, it has three major limitations that future research should overcome. 
Instead of using objective measures, the study used subjective measures of financial performance. Firstly, the nature of the enterprise studies made it impossible to use objective financial data. Secondly, the study adopted a cross-sectional research design. A longitudinal study would have provided more robust conclusions concerning the direct effects of strategy formulation on SME financial performance. Lastly, the study used data obtained from Zimbabwe, a developing country in Southern Africa, which obviously may affect the generalisability of the study findings to other African countries in different stages of development. However, the findings may be generalised to several countries in Africa with social, economic and institutional environments that are similar to those in Zimbabwe.

\section{Acknowledgements}

The authors would like to thank the University of KwaZuluNatal and the principal researcher's supervisor for the support they provided to Mr M.M. in attending the seminar on $\mathrm{PhD}$ research writing and article publishing in Pietermaritzburg (South Africa). The seminar provided important information and knowledge that made the writing of this article a success.

\section{Competing interests}

The authors have declared that no competing interests exist.

\section{Authors' contributions}

M.M. conducted literature review and the writing of the article, M.B. analysed the data and M.P. proofread the first draft of the manuscript and gave suggestions.

\section{Funding information}

This research received no specific grant from any funding agency in the public, commercial or not-for-profit sectors.

\section{Data availability}

The authors confirm that the data supporting the findings of this study are available within the article.

\section{Disclaimer}

The views and opinions expressed in this article are those of the authors and do not necessarily reflect the official policy or position of any affiliated agency of the authors.

\section{References}

Abosede, A.J., Obasan, K.A. \& Alese, O.J., 2016, 'Strategic management and small and medium enterprises (SMEs) development: A review of literature', International Review of Management and Business Research 3(2), 75-86.

Acquaah, M. \& Agyapong, A., 2015, 'The relationship between competitive strategy and firm performance in micro and small businesses in Ghana: The moderating role of managerial and marketing capabilities', Africa Journal of Management 1(2), 172-193. https://doi.org/10.1080/23322373.2015. 1025684
Adeyemi, I.I., Isaac, O.A. \& Olufemi, A.S., 2017, 'Strategic management: A policy, still, they sustainable business development in small and medium scale enterprises in
Nigeria', Archives of Business Research 5(9), 108-118. https://doi.org/10.14738/ abr.59.3638

Ahmad, K., 2014, 'The adoption of Management accounting practices in Malaysian Small and Medium-sized Enterprises', Asian Social Science 10(2), 236-249. https://doi.org/10.5539/ass.v10n2p236

Aldehayyat, J.S., 2015, 'Environmental scanning in business organisations: Empirical evidence from a Middle Eastern country context', Management Research Review 38(5), 459-481. https://doi.org/10.1108/MRR-02-2014-0032

Analoui, F. \& Karami, A., 2013, Strategic management in small and medium enterprises, Thomson Learning, London.

Anyanga, S.O. \& Nyamita, M.O., 2016, 'The major growth strategies adopted by small and medium enterprises in Kenya: A case of Kisumu County', International Journal of Advanced and Multidisciplinary Social Science 2(1), 11-26.

Auka, D.O. \& Langat, J.C., 2016, 'Effects of strategic planning on performance of medium sized enterprises in Nakuru Town', International Review of Management and Business Research 5(1), 188-203.

Birley, S. \& Westhead, P., 1990, 'Growth and performance contrasts between 'types' of small firms', Strategic Management Journal 11(7), 535-557. https://doi. org/10.1002/smj.4250110705

Bomani, M., 2017, 'Government policies and strategies in dealing with challenges confronting small and medium enterprises: A case of Harare, Zimbabwe', Unpublished PhD thesis, University of Kwazulu-Natal, Durban.

Burugo, V.M. \& Owour, D., 2017, 'Influence of strategic management practices on business profitability in Kenya: A case study of Chai trading company limited. Imperial Journal of Interdisciplinary Research 3(9), 923-947.

Carlsern, J \& Andersson, T.D., 2011, 'Strategic SWOT analysis for public, private and not-for- profit festival organisations', International Journal of Events and Festival Management 2(1), 83-97. https://doi.org/10.1108/17582951111116632

Chen, M. \& Liu, B., 2012, 'Strategic management in Chinese manufacturing SMEs', Unpublished dissertation, Master of Business Administration, Jonkoping International Business School, Jonkoping.

Cheng, W.H., Kadir, K.A. \& Bohari, A.M., 2014, 'The strategic planning of SMEs in Malaysia: A view of external environmental scanning', International Journal of Business and Society 15(3), 437-446.

Chinakidzwa, M. \& Phiri, M., 2020, 'Impact of digital marketing capabilities on market performance on small to medium enterprise agro-processors in Harare Zimbabwe', Business: Theory \& Practice 21(2), 746-757. https://doi.org/10.3846/ btp.2020.12149

Chong, H.G., 2008, 'Measuring performance of small and medium scale sized enterprises: The grounded theory approach', Journal of Business and Public Affairs 2(1), 1-10.

Cokins, G., 2017, Strategic business management: From planning to performance, John Wiley \& Sons, New York, NY.

Covin, J.G., 1991, 'Entrepreneurial versus conservative firms: A comparison of strategies and performance', Journal of Management Studies 28, 439-462. https://doi.org/10.1111/j.1467-6486.1991.tb00763.x

Dauda, Y.A., Akingbade, W.A. \& Akinlabi, H.B., 2010, 'Strategic management practice and corporate performance of selected small business enterprises in Lagos metropolis', International Journal of Business and Management 5(11), 97-105. https://doi.org/10.5539/ijbm.v5n11p97

David, F.R., 2013, Strategic management concepts, 13th edn., Pearson Education, Upper Saddle River, Hoboken, NJ.

David, F.R., 2015, Strategic management concept and cases: A competitive advantage approach, Pearson Education Inc., NJ.

David, M.E. \& David, F.R., 2016, 'The quantitative strategic planning matrix: A new marketing tool', Journal of Strategic Marketing 25(4), 342-352. https://doi.org/ $10.1080 / 0965254 X .2016 .1148763$

Dess, G.G., Lumpkin, T. \& Eisner, A.B., 2010, Strategic management: Texts \& cases, 5th edn., McGraw-Hill, New York, NY.

De Wit, R. \& Meyer, R., 2014, Strategy: Process, content, context, 4th edn., SouthWestern Cengage Learning, Boston, MA.

Donkor, J., Donkor, G.N.A. \& Kwarteng, C., 2018, 'Strategic planning and performance of SMEs in Ghana: The moderating effect of market dynamism', Asia Pacific Journal of Innovation and Entrepreneurship 12(1),62-76. https://doi.org/10.1108/ APJIE-10-2017-0035

Dubilihla, J. \& Sandada, M., 2014, 'Impact of strategic planning on small and mediumsized enterprises' performance: The role of employee participation, implementation incentives and evaluation and control', Journal of Economics 5(1), 45-55. https://doi.org/10.1080/09765239.2014.11884983

Du Toit, A., 2016, 'Using environmental scanning to collect strategic information: A South African survey', International Journal of Information Management 36(1), 16-24. https://doi.org/10.1016/j.ijinfomgt.2015.08.005Falshaw, J.R., Glaister, K.W. \& Tatoglu, E., 2006, 'Evidence of formal strategic planning and company performance', Management Decision 44(1), 9-30. https://doi.org/10.1108/00251740610641436

Feurer, R. \& Chaharbaghi, K., 1997, 'Strategy development: Past, present and future', Training for Quality 5(2), 58-70.

Galbreath, J., Lucianetti, L., Thomas, B. \& Tisch, D., 2020, 'Entrepreneurial orientation and firm performance in Italian firms: The moderating role of competitive strategy', International Journal of Entrepreneurial Behavior \& Research 26(4), 629-646. https://doi.org/10.1108/IJEBR-07-2019-0457

Gates, L.P., 2013, Strategic planning with critical success factors and future scenarios: An integrated strategic planning framework, Carnegie-Mellon University, Pittsburgh, PA. 
Germanos, G., 2012, 'The process of strategy formulation in small and medium enterprises in Greece and the role of accounting information', Unpublished PhD thesis, University of Birmingham, Birmingham.

Gomera, S., Chinyamurindi, W.T. \& Mishi, S., 2018, 'Relationship between strategic planning and financial performance: The case of small, micro- and medium-scale businesses in the Buffalo city metropolitan', South African Journal of Economic and Management Sciences 21(1), 1-9. https://doi.org/10.4102/sajems.v21i1.1634

Hadighi, A.S., Sahebjamnia, N., Mahdavi, I. \& Shirazi, M.A., 2013, 'A framework for strategy formulation based on clustering approach: A case study in a corporate organisation', Kwoledge-based Systems 49(2013), 37-49. https://doi.org/10.1016/j. knosys.2013.04.008

Hair, J.F., Babin, B.J., Anderson, R.E. \& Tatham, R.L., 2019, Multivariate data analysis: A global perspective, 8th edn., Prentice Hall, Hoboken, NJ.

Harif, M.A.A.M., Hoe, C.H. \& Ahmed, M.I., 2013, 'The financial and nonfinancial performance indicators of paddy framers' organizations in Kedah', World Review of Business Research 3(1), 80-102. https://doi.org/10.2139/ssrn.2130415

Hay, G.J. \& Castilla, G., 2006, 'Object-based image analysis: Strengths, Weaknesses, Opportunities and Threats (SWOT)', ISPRS Archives 36, 4-5.

Helms, M.M., Martín A., Rodríguez, M.A., De los Ríos, L. \& Hargrave, W.B., 2011 'Entrepreneurial potential in Argentina: A SWOT analysis', An International Business Journal incorporating Journal of Global Competitiveness 21(3), 269-287. https://doi.org/10.1108/10595421111134859

Hill, C.W.L. \& Jones, G., 2013, Strategic management theory: An integrated approach 9 th edn., Cengage Learning, Mason, $\mathrm{OH}$.

Jones, G.R. \& Hill, C.W., 2010, Theory of strategic management: With cases, SouthWestern Cengage Learning, Mason, $\mathrm{OH}$

Kee-Luen, W., Hiam-Yong, K. \& Seng-Fook, O., 2013, 'Strategic planning and business performance: A study of SMEs in Malaysia', in Proceedings of 3rd Asia-Pacific business research conference, 25-26 February 2013, Kuala Lumpur, pp. 1-25.

Kowo, S., Sabitu, O. \& Adegbite, G., 2018, 'Influence of competitive strategies on corporate performance of small and medium enterprises: A case from Nigeria',
Agricultural and Resource Economics: International Scientific E-Journal 4(3), 14-33

Lynch, R., 2015, Strategic management, 7th edn., Pearson Education, Edinburgh Gate.

Mabenge, B.K., Ngorora-Madzimure, G.P.A. \& Makanyeza, C., 2020, 'Dimensions of innovation and their effects on the performance of small and medium enterprises: The moderating role of firm's age and size', Journal of Small Business \& Entrepreneurship 4(1), 1-26. https://doi.org/10.1080/08276331.2020.1725727

Mageto, J., Prinsloo, G. \& Luke, R., 2018, 'Logistics outsourcing and performance of manufacturing small and medium-sized enterprises in Nairobi', Southern African
Journal of Entrepreneurship and Small Business Management 10(1), a162. https:// Journal of Entrepreneurship and Sma
doi.org/10.4102/sajesbm.v10i1.162

Majama, N.S. \& Magang, T., 2017, 'Strategic planning in small and medium enterprises (SMEs): A case study of Botswana SMEs', Journal of Management and Strategy 8(1), 74-103. https://doi.org/10.5430/jms.v8n1p74

Makanyeza, C. \& Dzvuke, G., 2015, 'The influence of innovation on the performance of small and medium enterprises in Zimbabwe', Journal of African Business 16(1-2), 198-214. https://doi.org/10.1080/15228916.2015.1061406

Mattheeusen, S. \& Spontak, T., 2018, 'Strategic planning in small and medium-sized enterprises in Sweden', Unpublished Master's research project of Lund University.

Mbengo, P., 2016, 'Marketing mix's influence on mobile banking adoption by the rural unbanked consumers in Masvingo province', unpublished PhD thesis, University of Kwazulu-Natal.

Melo, F.M.S., Sproesser, R.L., Silva, W.L. \& Souza, R., 2018, 'Business strategy and environmental practices: Evidence in the sugarcane energy sector in Brazil' African Journal of Business Management 12(2), 44-57. https://doi.org/10.5897/ AJBM2017.8463

Mintzberg, H., 1994, 'The fall and rise of strategic planning', in Harvard Business Review, January, pp. 107-114, viewed 08 April 2018, from https://hbr. org/1994/01/the-fall-and-rise-of-strategic-planning.

Mintzberg, H., Ahlstrand, B. \& Lampel, J., 2009, Strategy safari: Your complete guide through the wilds of strategic management, 2nd edn., Prentice Hall, Harlow.

Monday, J.U., Akinola, G.O., Ologbenla, P. \& Aladeraji, O.K., 2016, 'Strategic management and firm performance: A study of selected manufacturing companies in Nigeria', European Journal of Business and Management 79(2), 176-192.

Mugozhi, F. \& Hlabiso, G., 2017, 'Determinants of small to medium enterprises' success or failure: An ex-post appraisal of start-up business by young entrepreneurs
in Zimbabwe', The International Journal of Humanities \& Social Studies 5(3), 1-18.

Musandiwa, T.J., 2014, 'Customer orientation in small business marketing mix strategy formulation and implementation', PhD (Marketing) Unpublished, University of Johannesburg.

Mutengezenwa, M., 2018, 'Financial literacy among Small and medium enterprises in Zimbabwe', Unpublished DBA thesis, University of Kwazulu-Natal, Durban.

Nwachukwu, C., Chladkova, H. \& Fadeyi, O., 2017, 'Strategy formulation process and innovation performance nexus', International Journal for Quality Research 12(1) 147-164. https://doi.org/10.18421/IJQR12.01-09

Nyamwanza, T., 2015, 'Strategy implementation for survival and growth among small to medium-sized enterprises (SMES) in Zimbabwe', PhD thesis, Midlands State University, Gweru.

Omsa, S., Ridwan, M. \& Jayadi, M., 2017, 'The effect of strategic management practices on SME performances in Makassar, Indonesia', American Journal of Theoretical and Applied Business 3(4), 71-80. https://doi.org/10.11648/j. ajtab.20170304.12

Papulova, Z. \& Papula, J., 2014, 'Approaches to strategy: Practice of Slovak enterprises world', Journal of Social Sciences 4(2), 123-133.
Pashaa, O. \& Poisterb, T.H., 2017, 'Exploring the change in strategy formulation and performance measurement practices under turbulence', Public Performance \& Management Review 40(3), 504-528. https://doi.org/10.1080/15309576.2016.1 276843

Pitt, M. \& Koufopoulos, D., 2012, Essentials of strategic management, Sage Publications, London.

Pratiwi, A., Sutopo, W., Zakaria, R. \& Rasli, A.M., 2017, 'Formulating strategy through QSPM based on SWOT framework: A case study spin-off company in Malaysia' Advanced Science Letters 23(9), 8646-8651. https://doi.org/10.1166/asl.2017.9945

Pucci, T., Nosi, C. \& Zanni, L., 2017, 'Firm capabilities, business model design and performance of SMEs', Journal of Small Business and Enterprise Development 24(2), 222-241. https://doi.org/10.1108/JSBED-09-2016-0138

Ralph, I., Williams, J.R., Smith, A., Joshua, R., Aaron, B., Scott, C. et al., 2020, 'Small business strategic management practices and performance: A configurational approach', Economic Research-Ekonomska Istraživanja 33(1), 2378-2396. https:// doi.org/10.1080/1331677X.2019.1677488

Raymond, L., Marchand, M., St-Pierie, J., Cadieux, L. \& Labelle, F., 2013, 'Dimensions of small business performance from the owner-manager's perspective: A reconceptualization and empirical validation', Entrepreneurship and Regional Development 25(5-6), 468-499. https://doi.org/10.1080/08985626.2013.782344

Roscoe, J.T., 1975, Fundamental research statistics for the behavioural sciences, 2nd edn., Holt Rinehart \& Winston, New York, NY.

Salloum, C., Azzi, G., Mercier Suissa, C. \& Khalil, S., 2016, 'The impact of the presence of women in management on the firms' performance', International Journal of Entrepreneurship and Small Business 27(2-3), 213-246. https://doi.org/10.1504/ IJESB.2016.073976

Sami, W., 2016, 'Exploring the strategising practices of small business managers in selected small businesses in the accommodation sector in Tshwane metropolitan area', Unpublished Master of Commerce, Unpublished thesis, University of South Africa, Johannesburg.

Sandada, M., 2015, 'Strategic planning dimensions in small and medium enterprises (SMEs) in South Africa: Their relative importance and variations in selected demographic variables', Economic Forum Journal 4(1), 14-29.

Sandada, M. \& Chikwama, R.T., 2016, 'The driving forces for the practice of strategic planning in SMEs: Evidence from Harare metropolitan province, Zimbabwe', Acto Universitatis Danubius 12(6), 95-114.

Sarason, Y. \& Tegarden, F., 2003, 'The erosion of the competitive advantage of strategic planning', Journal of Business and Management 9(1), 1-21.

Saunders, M., Lewis, P. \& Thornhill, A., 2016, Research methods for business students, 7 th edn., Pearson India Education, Noida.

Sekaran, U. \& Bougie, R., 2016, Research methods for business: A skill building approach, 5th edn., Hermitage, New York, NY.

Shrader, C., Mulford, C. \& Blackburn, V., 1989, 'Strategic and operational planning, uncertainty, and performance in small firms', Journal of Small Business Management 27, 45-60.

Shu, C., De Clercq, D., Zhou, Y. \& Liu, C., 2019, 'Government institutional support, entrepreneurial orientation, strategic renewal, and firm performance in transitional China', International Journal of Entrepreneurial Behavior \& Research 25(3), 433-456. https://doi.org/10.1108/IJEBR-07-2018-0465

Sibanda, K., Hove-Sibanda, P. \& Shava, H., 2018, 'The impact of SME access to finance and performance on exporting behaviour at firm level: A case of furniture manufacturing SMEs in Zimbabwe', Acta Commercii 18(1), a554. https://doi. manufacturing SMEs in
org/10.4102/ac.v18i1.554

Siddique, C.M., 2015, 'A comparative study of strategic planning practices of SMEs and large-sized business organizations in emerging economies: The case of UAE', Strategic Change 24(6), 553-567. https://doi.org/10.1002/jsc.2039

Singh, S.P., 2009, Corporate strategy, 2nd edn., AITBS Publishers, New Delhi.

Tell, J., 2010, 'Managerial strategies in small, fast-growing manufacturing firms', Journal of Management Development 31(7), 700-710. https://doi. org/10.1108/02621711211243890

Thompson, Jr. A.A., Strickland, A.J., Gamble, J.E. \& Jain, A.K., 2016, Crafting and executing strategy: The quest for competitive advantage-concepts and cases, Tata McGraw-Hill Publishing Company Limited, New Delhi.

Tinarwo, T., 2016, 'An investigation into the challenges faced by small to medium enterprises in Zimbabwe: A case of Gazaland market', Journal of Business and Management 18(9), 148-153. https://doi.org/10.9790/487X-180902148153

Verreynne, M.L., Meyer, D. \& Liesch, P., 2014, 'Beyond the formal-informal dichotomy of small firm Strategy-making in stable and dynamic environments', Journal of Small Business Management 54(2), 420-444. https://doi.org/10.1111/ jsbm.12143

Wang, G., Dou, W., Zhu, W. \& Zhou, N., 2015, 'The effects of firm capabilities on external collaboration and performance: The moderating role of market turbulence', Journal of Business Research 68(9), 1928-1936. https://doi. org/10.1016/j.jbusres.2015.01.002

Wheelen, T.L. \& Hunger, J.D., 2014, Strategic management and business policy, 13th edn., Prentice Hall Inc., New York, NY.

Wheelen, T.L., Hunger, J.D., Hoffman, A.N. \& Bamford, C.E., 2014, Strategic management and business policy: Globalization, innovation and sustainability, 14th edn., Prentice Hall Inc., New York, NY.

Wiesner, R. \& Millet, B., 2012, 'Strategic approaches in Australian SMEs: Deliberate or emergent?', Journal of Management \& Organization 18(1), 98-122. https://doi. org/10.1017/S1833367200001097 